PEDIOMATERNAL
NURSING JOURNAL
Vol. 5, No. 1, Maret 2019
Jediomaternal
Journal Homepage: https://e-journal.unair.ac.id/PMNJ//

Original Research

\title{
Pendidikan Kesehatan Jigsaw dan Make a Match dalam Mencegah Fluor Albus pada Remaja Pondok Pesantren
}

\author{
(Jigsaw Health Education and Make a Match in Preventing Fluor Albus in Youth Islamic \\ Boarding Schools)
}

\author{
Laily Bestari Putri, Esti Yunitasari, dan Praba Diyan Rachmawati \\ Fakultas Keperawatan, Universitas Airlangga, Surabaya, Jawa Timur, Indonesia
}

\author{
ARTICLE HISTORY \\ Received: March 17, 2019 \\ Accepted: May 19, 2019

\section{KEYWORDS} \\ jigsaw; make a match; behavior; \\ fluor albus; adolescent

\section{CORRESPONDING AUTHOR} \\ Laily Bestari Putri \\ laily.bestari.putri- \\ 2017@fkp.unair.ac.id \\ Fakultas Keperawatan, \\ Universitas Airlangga, Surabaya, \\ Jawa Timur, Indonesia
} \begin{abstract}
Introduction: : Fluor albus is experienced by adolescents which is equal to $75 \%$, especially adolescents in islamic boarding schools because less of information about their reproductive health. Promotive and preventive efforts need to be carried out by conducting appropriate health education, namely the Jigsaw and Make a Match methods about personal hygiene. This study aims to determine the effect of Jigsaw and Make a Match health education methods to prevent fluor albus.

Methods: This study used the Quasy Experiment design which was divided into 3 groups (Jigsaw, Make a Match, and control). The number of samples used was 108 of 1,856 students. The sampling technique uses Simple Random Sampling by randomizing Nomer Induk Siswa Nasional. Independent variables are Jigsaw and Make a Match health education methods. Dependent variable is fluor albus prevention behavior. The instruments used were 3 questionnaires and 1 observation sheet that had been tested for validity and reliability with results in the knowledge category $r=0.935$, attitude categories $r=0.936$, and actions $r=0.921$. Data analysis using the Wilcoxon Signed Rank Test and Kruskal Wallis test.
\end{abstract}

Results: Health education using the Jigsaw method has a greater result than the Make a Match method in increasing fluor albus prevention behavior with the results of Willcoxon analysis $\mathrm{p}=0.0000$ and the mean in the Kruskall Wallis analysis the knowledge category is 84.35 , attitude is 82.03 , action is 79.49 , and action observations amounted to 79.46 .

Conclusion: Health education using Jigsaw and Make a Match methods is used to develop health promotion nursing interventions to improve fluor albus prevention behavior.

Putri, L. B., Yunitasari, E., \& Rachmawati, P. D. (2019). Pendidikan Kesehatan Jigsaw dan Make a Match dalam Mencegah Fluor Albus pada Remaja Pondok Pesantren. Pediomaternal Nurs. J., 5(1), 109-118.

\section{PENDAHULUAN}

Permasalahan pada organ reproduksi masih banyak ditemukan pada remaja karena kurangnya informasi mengenai kesehatan reproduksinya. Remaja juga masih sering mengabaikan masalah organ reproduksinya (Rakhmilla. L, et.al, 2016). Dibutuhkan upaya preventif dan promotif remaja memiliki perilaku yang baik dalam menjaga organ reproduksinya tetap sehat (2). Upaya preventif dan promotif yang dapat dilakukan yaitu memberikan pendidikan kesehatan yang tepat karena pendidikan kesehatan terbukti dapat lebih bermanfaat bila dilakukan pada suatu komunitas (3). Promosi kesehatan dan pendidikan kesehatan juga merupakan prioritas utama pada seluruh layanan kesehatan (4).

Upaya untuk mencegah masalah pada organ reproduksi yaitu dengan memperhatikan personal hygiene. Jika seseorang kurang memperhatikan personal hygienenya, maka bakteri akan berkembang biak dalam tubuh sehingga dapat menyebabkan suatu penyakit. Fluor albus dapat mengganggu ketidaknyamanan penderita karena disertai dengan aroma yang tidak sedap atau gatal. Bila fluor albus 
tidak segera ditangani, dapat berakibat pada iritasi, infeksi, dan penyakit yang lebih parah (5).

Menurut survei, sekitar $75 \%$ wanita di dunia pernah mengalami fluor albus sekali seumur hidupnya (6). Fluor albus patologis yang paling banyak disebabkan oleh Bacterial Vaginosis yakni sebesar 40\%-50\% (7). Remaja yang mengalami fluor albus di Jawa Timur sebesar 75\% (8). Kelompok santriwati juga mengalami masalah pada organ reproduksi. Berdasarkan survei yang dilakukan oleh (9) pada salah satu pondok pesantren di Jombang, terdapat $72,05 \%$ santriwati mengalami fluor albus, lingkungan pesantren yang memiliki sanitasi yang buruk yakni sebesar 69,9\%, dan personal hygiene santriwati yang buruk yaitu sebesar $65,6 \%$.

Berdasarkan studi pendahuluan yang dilakukan tanggal 15 Oktober 2018 pada 18 santriwati melalui wawancara terbuka mengenai pendapatnya tentang fluor albus, 7 dari 18 (39\%) santriwati hanya mengetahui tentang definisi fluor albus. 15 dari 18 $(83,3 \%)$ santriwati yang dilakukan wawancara terbuka berpendapat bahwa tindakan pencegahan fluor albus perlu dilakukan, namun santriwati belum paham mengenai jenis tindakan untuk mencegah terjadinya fluor albus.

Kehidupan di pesantren memiliki karakteristik berbeda dengan lembaga pendidikan lain. Karakteristik kehidupan pesantren seperti jarangnya berganti pakaian selama satu hari, serta penggunaan kamar mandi yang bersamaan menyebabkan penularan penyakit mudah terjadi. Remaja juga kurang memperhatikan hygiene saat menstruasi (10). Hal ini dapat mengakibatkan daerah genetalia lembab dan menjadi tempat berkembangnya bakteri sehingga menyebabkan fluor albus (11).

Fluor albus terjadi karena adanya ketidakseimbangan $\mathrm{pH}$ dalam vagina. $\mathrm{pH}$ vagina dipengaruhi oleh 2 faktor, yaitu faktor internal (hormon estrogen dan progesteron) dan eksternal (kurangnya personal hygiene) yang dapat menyebabkan berkembangnya bakteri, jamur penyebab fluor albus. (Kristiana; Sa'adatun. U \& Widyasih. H, 2018). Jika keputihan abnormal tidak segera diobati, hal ini dapat menyebabkan terganggunya fungsi organ reproduksi diantaranya penyakit radang panggul, infertilitas, kehamilan ektopik, dan nyeri panggul kronis (12). Selain fluor albus, personal hygiene yang buruk juga dapat menyebabkan vulvovaginitis (13). Tingginya angka kejadian fluor albus di pondok pesantren salah satunya disebabkan oleh kurangnya pengetahuan santriwati tentang fluor albus dan cara pencegahan fluor albus. Tindakan pencegahan perlu dilakukan untuk mencegah terjadinya fluor albus berulang (14).

Menurut Teori Precede-Proceed Model yang dikemukakan oleh Lawrence W. Green, perilaku kesehatan seseorang dipengaruhi oleh 3 faktor, yaitu faktor predisposisi, faktor pendukung, dan faktor pendorong. Ketiga faktor tersebut dapat dipengaruhi oleh faktor pendidikan kesehatan. Program pengajaran terstruktur perlu dilakukan untuk meningkatkan pengetahuan tentang fluor albus (15).
Inovasi dan kreatifitas terhadap metode pendidikan kesehatan dibutuhkan agar materi yang diberikan dapat diterima siswa dengan baik sehingga dapat meningkatkan perilaku pencegahan fluor albus (16). Jigsaw merupakan model pembelajaran yang menekankan pada kerjasama antar anggota kelompok yang dapat meningkatkan pengetahuan, sikap, dan keterampilan tiap anggota kelompok secara independen dan kolaboratif (17). Model pembelajaran Make a Match merupakan model pembelajaran cooperative learning yang bertujuan agar para siswa dapat berperan aktif dalam proses pembelajaran yang menyenangkan dan berdiskusi dengan individu lain mengenai suatu permasalahan (18). Dengan adanya proses diskusi tersebut, terjadi proses komunikasi persuasif yang bertujuan untuk mengubah kepercayaan, sikap, dan perilaku seseorang (19). Penelitian ini bertujuan untuk menjelaskan pendidikan kesehatan metode jigsaw dan Make a Match dalam meningkatkan perilaku pencegahan fluor albus pada remaja pondok pesantren.

\section{METODE}

\subsection{Desain}

Desain penelitian adalah Quasy Experiment pre and post test with control group design.

\subsection{Populasi, sampel, dan sampling}

Populasi dalam penelitian ini adalah seluruh santriwati Pondok Pesantren Tebuireng, Pondok Pesantren Darussalam, dan Pondok Pesantren Darul Ulum sebanyak 1.856 orang. dan didapatkan 108 santriwati dengan simple random sampling. Penelitian ini dilaksanakan pada 6-13 Desember 2018. Tidak ada kriteria eksklusi dalam penelitian ini. Kriteria inklusi adalah santriwati kategori remaja tengah yaitu berusia 16-17 tahun, dan santriwati yang tinggal di asrama pondok pesantren.

\subsection{Variabel}

Variabel independen yang digunakan dalam penelitian ini adalah pendidikan kesehatan metode Jigsaw dan Make a Match. Variabel dependen dalam penelitian ini adalah perilaku pencegahan fluor albus pada remaja pondok pesantren degan sub variabel pengetahuan, sikap, dan tindakan.

\subsection{Instrumen}

Kuesioner pengetahuan remaja tentang fluor albus terdapat 13 pertanyaan yang dibuat oleh peneliti dikembangkan dari kuesioner penelitian sebelumnya oleh (Rakhmilla. L, Fah. L, Yulia. S, 2016). Kuesioner sikap remaja tentang fluor albus menggunakan skala Likert yang terdiri dari 13 pertanyaan yang dibuat oleh peneliti dikembangkan dari kuesioner penelitian sebelumnya oleh (20). Kuesioner tindakan remaja tentang fluor albus menggunakan skala Likert yang terdiri dari 8 pertanyaan yang dibuat oleh peneliti dikembangkan dari kuesioner penelitian sebelumnya 
oleh (20). Kuesioner observasi tindakan remaja tentang fluor albus terdapat 9 pertanyaan.

\subsection{Prosedur}

Peneliti mendatangi Pondok Pesantren Tebuireng sebagai kelompok Make a Match, Pondok Pesantren Darussalam sebagai kelompok Jigsaw, dan Pondok Pesantren Darul Ulum sebagai kelompok kontrol untuk meminta ijin melakukan intervensi pendidikan kesehatan. Kemudian peneliti membagi sampel menjadi 3 kelompok (kelompok intervensi metode Jigsaw, kelompok intervensi metode Make a Match, dan kelompok kontrol). Sampel dibagi berdasarkan kelompok umur yang sama yaitu remaja tengah berusia 16-17 tahun.

Pada hari pertama, peneliti menuju kelompok kontrol yaitu Pondok Pesantren Darul Ulum. Peneliti menjelaskan maksud dan tujuan penelitian pada siswa. Kemudian para siswa diberikan kuesioner berupa soal pre test untuk dikerjakan. Setelah mengisi kuesioner, peneliti meminta siswa untuk mengumpulkan kuesioner satu per satu. Setelah proses pengumpulan kuesioner, peneliti memberikan pertanyaan dan meminta siswa untuk mendemonstrasikan mengenai soal-soal pada lembar observasi. Setelah seluruh siswa mendemonstrasikan soal-soal pada lembar observasi, peneliti mengakhiri kegiatan dan kontrak waktu untuk pelaksanaan post test pada pertemuan selanjutnya. Kelompok kontrol tidak diberikan materi mengenai fluor albus.

Pada hari kedua sebelum diakukan metode Jigsaw yaitu Pondok Pesantren Darussalam, peneliti membagikan pre test pada siswa untuk dikerjakan. Setelah mengerjakan pre test, peneliti menjelaskan prosedur lalu kelas dibagi menjadi 6 tim yang disebut kelompok awal. Tiap anggota pada 1 tim kelompok awal mempelajari satu materi yang diberikan. Materi yang dipelajari dapat berupa: pengertian fluor albus, ciri dan klasifikasi, penyebab, dampak, dan pencegahan fluor albus. Pada kelompok ini tidak ada proses diskusi. Siswa diberi waktu 15 menit untuk mempelajari materi.

Setelah selesai mempelajari materi, masingmasing anggota pada kelompok awal bergabung dengan kelompok baru yang disebut kelompok ahli. Kelompok ahli terdiri dari 6 anggota yang memiliki materi yang sama. Siswa yang pada kelompok awal mempelajari pengertian fluor albus bergabung membentuk kelompok baru yang disebut kelompok ahli, dan seterusnya. Kelompok yang mempelajari materi tentang tindakan pencegahan fluor albus memiliki tanggungjawab tambahan yakni mendemonstrasikan tindakan pencegahan fluor albus saat kembali ke kelompok awal. Waktu yang diberikan untuk berdiskusi saat berada di kelompok ahli adalah 15 menit. Setelah proses diskusi selesai, anggota kelompok ahli kembali ke kelompok awal untuk menyampaikan materinya saat berada pada kelompok ahli selama 15 menit. Tiap proses diskusi di kelompok ahli dan kelompok awal terdapat 1 fasilitator yang bertugas memantau dan mengarahkan proses diskusi.
Kemudian, peneliti merangkum materi, menjawab pertanyaan yang belum terjawab dan melakukan kontrak waktu untuk pertemuan berikutnya dengan materi sama yang diacak, serta melakukan evaluasi dengan memberikan pertanyaan terkait materi yang telah didiskusikan.

Hari berikutnya, peneliti menuju ke kelompok intervensi metode Make a Match yaitu Pondok Pesantren Tebuireng. Peneliti membagikan soal pre test untuk dikerjakan oleh responden. Kemudian, peneliti menjelaskan prosedur penelitian. Setelah menjelaskan prosedur peneitian, peneliti membagi kelas menjadi 2 kelompok besar (tim pertanyaan, dan tim jawaban). Tiap tim memiliki 1 fasilitator. Peneliti memberikan kartu berisi soal dan jawaban yang diberikan sesuai tim. Kemudian siswa mencari pasangan setiap kartu yang dibatasi oleh waktu yaitu 10 menit. Setelah 10 menit, tiap pasangan mendiskusikan materi sesuai kartunya selama 10 menit. Kemudian tiap pasangan kartu mempresentasikan hasil pertanyaan dan jawaban kartunya didepan kelas selama 15 menit. Pasangan kartu tentang tindakan pencegahan fluor albus memiliki tanggung jawab tambahan yakni mendemonstrasikan tindakan pencegahan fluor albus. Babak ini berlangsung 1x yang dilakukan selama 45 menit. Di akhir babak, pemateri merangkum semua materi yang telah diberikan dan kontrak waktu untuk pertemuan berikutnya dengan materi sama namun dengan tim yang diacak, serta melakukan evaluasi dengan memberikan pertanyaan terkait materi yang telah didiskusikan

Post test seluruh kelompok dilakukan 4 hari setelah selesai dilakukan pendidikan kesehatan Jigsaw dan Make a Match. Mengacu pada penelitian oleh (21), evaluasi dapat dilakukan dalam rentang waktu antara 1-7 hari setelah intervensi.

\subsection{Analisis}

Penelitian ini dilakukan analisis dengan IBM SPSS Statistic 25 menggunakan uji statistik Wilcoxon Signed Test untuk menganalisa selisih hasil pre dan post test pada tiap variabel dan tiap kelompok, dan Kruskal Wallis untuk menganalisa hasil mean tertinggi pada tiap kelompok dengan tingkat kemaknaan $\mathrm{p} \leq 0,05$

\subsection{Ethical Clearance}

Penelitian ini telah dinyatakan lolos kaji etik no.1246KEPK oleh Komisi Etik Penelitian Kesehatan Fakultas Keperawatan Universitas Airlangga.

\section{Hasil}

Pengetahuan remaja pada kelompok Jigsaw saat pretest sebagian besar berpengetahuan kurang, yaitu sebanyak 17 remaja $(47,2 \%)$, saat posttest sebanyak 28 remaja $(77,8 \%)$ berpengetahuan baik. pada kelompok Make a Match saat pretest sebagian besar berpengetahuan kurang, yaitu sebanyak 15 remaja $(41,7 \%)$ sedangkan saat posttest sebanyak 20 remaja $(55,6 \%)$ berpengetahuan baik. Pada kelompok 


\section{B. PUTRI ET AL.}

kontrol saat pretest sebagian besar berpengetahuan kurang, yaitu sebanyak 13 remaja $(36,1 \%)$ sedangkan saat posttest sebanyak 13 remaja $(36,1 \%)$ berpengetahuan cukup. Hasil analisis Wilcoxon Signed Ranks Test pada kelompok Jigsaw dan Make a Match diperoleh nilai $\mathrm{p}=0,000$ sehingga $\mathrm{p}<0,05$ yang berarti ada perbedaan pengetahuan yang signifikan saat pretest dan posttest. Pada kelompok kontrol diperoleh nilai $\mathrm{p}=0,248$ sehingga $\mathrm{p}>0,05$ yang berarti tidak ada perbedaan pengetahuan yang signifikan saat pretest dan posttest. Analisis Kruskal Wallis $\mathrm{p}<0,05$ yang berarti ada perbedaan sikap yang signifikan saat pretest dan posttest. Pada kelompok kontrol diperoleh nilai $p=0,1000$ sehingga $p>0,05$ yang berarti tidak ada perbedaan sikap yang signifikan saat pretest dan posttest. Analisis Kruskal Wallis diperoleh nilai $\mathrm{p}=0,000$ sehingga $\mathrm{p}<0,05$ yang berarti ada perbedaan sikap antara kelompok Jigsaw, Make a Match, dan kelompok kontrol. Hasil mean pada analisis Kruskal Wallis pada kategori sikap kelompok Jigsaw diperoleh nilai 82,03, pada kelompok Make a Match diperoleh nilai 62,17, dan

Tabel 1. Distribusi pengetahuan remaja tentang pencegahan fluor albus sebelum dan setelah diberikan pendidikan kesehatan dengan metode pembelajaran Jigsaw dan Make a Match di Pondok Pesantren (n=108)

\begin{tabular}{|c|c|c|c|c|c|c|c|c|c|c|c|c|}
\hline \multirow{3}{*}{ Pengetahuan } & \multicolumn{4}{|c|}{ Kelompok Jigsaw } & \multicolumn{4}{|c|}{ Kelompok Make a Match } & \multicolumn{4}{|c|}{ Kelompok Kontrol } \\
\hline & \multicolumn{2}{|c|}{ Pre } & \multicolumn{2}{|c|}{ Post } & \multicolumn{2}{|c|}{ Pre } & \multicolumn{2}{|c|}{ Post } & \multicolumn{2}{|c|}{ Pre } & \multicolumn{2}{|c|}{ Post } \\
\hline & $\mathbf{n}$ & $\%$ & $\mathbf{n}$ & $\%$ & $\mathbf{n}$ & $\%$ & $\mathbf{n}$ & $\%$ & n & $\%$ & n & $\%$ \\
\hline Baik & 9 & 25 & 28 & 77,8 & 10 & 27,8 & 20 & 55,6 & 12 & 33,3 & 12 & 33,3 \\
\hline Cukup & 10 & 27,8 & 8 & 22,2 & 11 & 30,6 & 16 & 44,4 & 11 & 30,6 & 13 & 36,1 \\
\hline Kurang & 17 & 47,2 & 0 & 0 & 15 & 41,7 & 0 & 0 & 13 & 36,1 & 11 & 30,6 \\
\hline Mean & \multicolumn{4}{|c|}{84,35} & \multicolumn{4}{|c|}{53,21} & \multicolumn{4}{|c|}{25,94} \\
\hline $\begin{array}{l}\text { Wilcoxon Signed } \\
\text { Ranks Test }\end{array}$ & \multirow{2}{*}{\multicolumn{4}{|c|}{$\mathrm{p}=0,000$}} & \multicolumn{4}{|c|}{$p=0,000$} & \multirow{2}{*}{\multicolumn{4}{|c|}{$\mathrm{p}=0,248$}} \\
\hline Kruskal Wallis & & & & & & & 00 & & & & & \\
\hline
\end{tabular}

Tabel 2. Distribusi sikap remaja tentang pencegahan fluor albus sebelum dan setelah diberikan pendidikan kesehatan dengan metode pembelajaran Jigsaw dan Make a Match di Pondok Pesantren (n=108)

\begin{tabular}{|c|c|c|c|c|c|c|c|c|c|c|c|c|}
\hline \multirow{3}{*}{ Sikap } & \multicolumn{4}{|c|}{ Kelompok Jigsaw } & \multicolumn{4}{|c|}{ Kelompok Make a Match } & \multicolumn{4}{|c|}{ Kelompok Kontrol } \\
\hline & \multicolumn{2}{|c|}{ Pre } & \multicolumn{2}{|c|}{ Post } & \multicolumn{2}{|c|}{ Pre } & \multicolumn{2}{|c|}{ Post } & \multicolumn{2}{|c|}{ Pre } & \multicolumn{2}{|c|}{ Post } \\
\hline & $\mathbf{n}$ & $\%$ & $\mathbf{n}$ & $\%$ & $\mathbf{n}$ & $\%$ & $\mathbf{n}$ & $\%$ & $\mathbf{n}$ & $\%$ & $\mathbf{n}$ & $\%$ \\
\hline Positif & 14 & 38,9 & 23 & 63,9 & 16 & 44,4 & 20 & 55,6 & 15 & 41,7 & 15 & 41,7 \\
\hline Negatif & 22 & 61,1 & 13 & 36,1 & 20 & 55,6 & 16 & 44,4 & 21 & 58,3 & 21 & 58,3 \\
\hline Total & 36 & 100 & 36 & 100 & 36 & 100 & 36 & 100 & 36 & 100 & 36 & 100 \\
\hline Mean & \multicolumn{4}{|c|}{82,03} & \multicolumn{4}{|c|}{62,17} & \multicolumn{4}{|c|}{19,31} \\
\hline $\begin{array}{l}\text { Wilcoxon Signed } \\
\text { Ranks Test }\end{array}$ & \multirow{2}{*}{\multicolumn{4}{|c|}{$\mathrm{p}=0,000$}} & \multicolumn{4}{|c|}{$p=0,000$} & \multirow{2}{*}{\multicolumn{4}{|c|}{$P=0,1000$}} \\
\hline Kruskal Wallis & & & & & & & 000 & & & & & \\
\hline
\end{tabular}

diperoleh nilai $\mathrm{p}=0,000$ sehingga $\mathrm{p}<0,05$ yang berarti ada perbedaan pengetahuan antara kelompok Jigsaw, Make a Match, dan kelompok kontrol. Hasil mean pada analisis Kruskal Wallis pada pengetahuan kelompok Jigsaw diperoleh nilai 84,35, pada kelompok Make a Match diperoleh nilai 53,21, dan pada kelompok kontrol diperoleh nilai 25,94 [Tabel 1].

Sikap remaja pada kelompok Jigsaw saat pretest sebagian besar memiliki sikap negatif, yaitu sebanyak 22 remaja $(61,1 \%)$ sedangkan saat posttest sebanyak 23 remaja $(63,9 \%)$ memiliki sikap positif. Pada kelompok Make a Match saat pretest sebagian besar memiliki sikap negatif, yaitu sebanyak 20 remaja $(55,6 \%)$ sedangkan saat posttest sebanyak 20 remaja (55,6\%) memiliki sikap positif, dan sebanyak 16 remaja $(44,4 \%)$ memiliki sikap negatif. Pada kelompok kontrol saat pretest sebagian besar memiliki sikap negatif, yaitu sebanyak 15 remaja $(58,3 \%)$ sedangkan saat posttest sebanyak 15 remaja (58,3\%) memiliki sikap negatif. Hasil analisis Wilcoxon Signed Ranks Test pada kelompok Jigsaw dan Make a Match diperoleh nilai $\mathrm{p}=0,000$ sehingga pada kelompok kontrol diperoleh nilai 19,31 [Tabel 2].

Tindakan remaja pada kelompok Jigsaw saat pretest sebagian besar memiliki tindakan negatif, yaitu sebanyak 22 remaja $(61,1 \%)$ sedangkan saat posttest sebanyak 21 remaja (58,3\%) memiliki tindakan positif. Pada kelompok Make a Match saat pretest sebagian besar memiliki tindakan negatif dan positif, yaitu masing-masing sebanyak 18 remaja (50\%) sedangkan saat posttest sebanyak 20 remaja $(55,6 \%)$. Pada kelompok kontrol saat pretest sebagian besar memiliki tindakan negatif, yaitu sebanyak 20 remaja $(44,4 \%)$ sedangkan saat posttest sebanyak 19 remaja (52,8\%) memiliki tindakan negatif. Hasil analisis Wilcoxon Signed Ranks Test pada kelompok Jigsaw dan Make a Match diperoleh nilai $\mathrm{p}=0,000$ sehingga $\mathrm{p}<0,005$ yang berarti ada perbedaan tindakan yang signifikan saat pretest dan posttest. Pada kelompok kontrol diperoleh nilai $p=0,1000$ sehingga $p>0,005$ yang berarti tidak ada perbedaan tindakan yang signifikan saat pretest dan posttest. Analisis Kruskal Wallis diperoleh nilai $\mathrm{p}=0,000$ sehingga $\mathrm{p}<0,05$ yang berarti ada perbedaan 
tindakan antara kelompok Jigsaw, Make a Match, dan kelompok kontrol. Hasil mean pada analisis Kruskal Wallis pada kategori tindakan kelompok Jigsaw diperoleh nilai 79,49. Pada kelompok Make a Match diperoleh nilai 62,35, dan pada kelompok kontrol diperoleh nilai 21, 67 [Tabel 3].

Observasi tindakan remaja pada kelompok Jigsaw saat pretest sebagian besar memiliki tindakan cukup, yaitu sebanyak 15 remaja (41,7\%) sedangkan saat posttest sebanyak 30 remaja $(83,3 \%)$ memiliki tindakan baik. Pada kelompok Make a Match saat pretest sebagian besar memiliki tindakan kurang, yaitu sebanyak 15 remaja (41,7\%) sedangkan saat
52,44 , dan pada kelompok kontrol diperoleh nilai 31,60 [Tabel 4].

\section{PEMBAHASAN}

4.1 Pengaruh Pendidikan Kesehatan Metode Jigsaw dan Make a Match terhadap Pengetahuan

Pencegahan Fluor albus pada Remaja

Pendidikan kesehatan metode Jigsaw berpengaruh terhadap pengetahuan pencegahan fluor albus pada responden. Pengetahuan responden meningkat setelah mendapatkan pendidikan kesehatan dengan menggunakan metode Jigsaw disebabkan karena

Tabel 3 Distribusi tindakan remaja tentang pencegahan fluor albus sebelum dan setelah diberikan pendidikan kesehatan dengan metode pembelajaran Jigsaw dan Make a Match di Pondok Pesantren

\begin{tabular}{|c|c|c|c|c|c|c|c|c|c|c|c|c|}
\hline \multirow{3}{*}{ Tindakan } & \multicolumn{4}{|c|}{ Kelompok Jigsaw } & \multicolumn{4}{|c|}{ Kelompok Make a Match } & \multicolumn{4}{|c|}{ Kelompok Kontrol } \\
\hline & \multicolumn{2}{|c|}{ Pre } & \multicolumn{2}{|c|}{ Post } & \multicolumn{2}{|c|}{ Pre } & \multicolumn{2}{|c|}{ Post } & \multicolumn{2}{|c|}{ Pre } & \multicolumn{2}{|c|}{ Post } \\
\hline & $\mathbf{n}$ & $\%$ & $\mathbf{n}$ & $\%$ & $\mathbf{n}$ & $\%$ & n & $\%$ & $\mathbf{n}$ & $\%$ & $\mathbf{n}$ & $\%$ \\
\hline Positif & 14 & 38,9 & 21 & 58,3 & 18 & 50 & 20 & 55,6 & 16 & 55,6 & 17 & 47,2 \\
\hline Negatif & 22 & 61,1 & 15 & 41,7 & 18 & 50 & 16 & 44,4 & 20 & 44,4 & 19 & 52,8 \\
\hline Total & 36 & 100 & 36 & 100 & 36 & 100 & 36 & 100 & 36 & 100 & 36 & 100 \\
\hline Mean & \multicolumn{4}{|c|}{79,49} & \multicolumn{4}{|c|}{62,35} & \multicolumn{4}{|c|}{21,67} \\
\hline $\begin{array}{l}\text { Wilcoxon Signed Ranks } \\
\text { Test }\end{array}$ & \multicolumn{4}{|c|}{$\mathrm{p}=0,000$} & \multicolumn{4}{|c|}{$\mathrm{p}=0,000$} & \multicolumn{4}{|c|}{$p=0,1000$} \\
\hline Kruskal Wallis & \multicolumn{12}{|c|}{$p=0,000$} \\
\hline
\end{tabular}

Tabel 4 Distribusi observasi tindakan remaja tentang pencegahan Fluor albus sebelum dan setelah diberikan pendidikan kesehatan dengan metode pembelajaran Jigsaw dan Make a Match di Pondok Pesantren

\begin{tabular}{|c|c|c|c|c|c|c|c|c|c|c|c|c|}
\hline \multirow{3}{*}{ Observasi Tindakan } & \multicolumn{4}{|c|}{ Kelompok Jigsaw } & \multicolumn{4}{|c|}{ Kelompok Make a Match } & \multicolumn{4}{|c|}{ Kelompok Kontrol } \\
\hline & \multicolumn{2}{|c|}{ Pre } & \multicolumn{2}{|c|}{ Post } & \multicolumn{2}{|c|}{ Pre } & \multicolumn{2}{|c|}{ Post } & \multicolumn{2}{|c|}{ Pre } & \multicolumn{2}{|c|}{ Post } \\
\hline & $\mathbf{n}$ & $\%$ & $\mathbf{n}$ & $\%$ & $\mathbf{n}$ & $\%$ & $\mathbf{n}$ & $\%$ & $\mathbf{n}$ & $\%$ & $\mathbf{n}$ & $\%$ \\
\hline Baik & 8 & 22,2 & 30 & 83,3 & 10 & 27,8 & 11 & 30,6 & 7 & 19,4 & 9 & 25 \\
\hline Cukup & 15 & 41,7 & 6 & 16,7 & 11 & 30,6 & 25 & 69,4 & 18 & 50 & 20 & 80,6 \\
\hline Kurang & 13 & 36,1 & 0 & 0 & 15 & 41,7 & 0 & 0 & 11 & 30,6 & 7 & 19,4 \\
\hline Total & 36 & 100 & 36 & 100 & 36 & 100 & 36 & 100 & 36 & 100 & 36 & 100 \\
\hline Mean & \multicolumn{4}{|c|}{79,46} & \multicolumn{4}{|c|}{52,44} & \multicolumn{4}{|c|}{31,60} \\
\hline $\begin{array}{l}\text { Wilcoxon Signed Ranks } \\
\text { Test }\end{array}$ & \multirow{2}{*}{\multicolumn{4}{|c|}{$\mathrm{p}=0,000$}} & \multicolumn{4}{|c|}{$\mathrm{p}=0,000$} & \multirow{2}{*}{\multicolumn{4}{|c|}{$\mathrm{p}=0,317$}} \\
\hline Kruskal Wallis & & & & & & $\mathrm{p}=$ & 000 & & & & & \\
\hline
\end{tabular}

posttest sebanyak 25 remaja $(69,4 \%)$ memiliki tindakan cukup. Pada kelompok kontrol saat pretest sebagian besar memiliki tindakan cukup, yaitu sebanyak 18 remaja (50\%) sedangkan saat posttest sebanyak 20 remaja $(80,6 \%)$ memiliki tindakan cukup. Hasil analisis Wilcoxon Signed Ranks Test pada kelompok Jigsaw dan Make a Match diperoleh nilai $\mathrm{p}=0,000$ sehingga $\mathrm{p}<0,05$ yang berarti ada perbedaan pengetahuan yang signifikan saat pretest dan posttest. Pada kelompok kontrol diperoleh nilai $p=0,317$ sehingga $p>0,05$ yang berarti tidak ada perbedaan pengetahuan yang signifikan saat pretest dan posttest. Pada analisis Kruskal Wallis diperoleh nilai $\mathrm{p}=0,000$ sehingga $\mathrm{p}<0,05$ yang berarti ada perbedaan observasi tindakan antara kelompok Jigsaw, Make a Match, dan kelompok kontrol. Hasil mean pada analisis Kruskal Wallis pada kategori observasi tindakan kelompok Jigsaw diperoleh nilai 79,46, pada kelompok Make a Match diperoleh nilai penerapan model pembelajaran Jigsaw dapat memberikan suasana belajar yang berbeda dengan kebiasaan belajar di Pondok Pesantren Darussalam. Responden tertarik untuk ikut serta dalam seluruh kegiatan pendidikan kesehatan dengan metode Jigsaw karena menonjolkan kualitas interaksi antar peserta melalui beberapa tahap sesi diskusi yang dapat meningkatkan komunikasi antar anggota, tanggungjawab tiap individu, tatap muka, dan proses evaluasi (22).

Metode pembelajaran Jigsaw tidak hanya dapat meningkatkan pemahaman mengenai suatu materi, namun dapat mendorong kerjasama antar siswa dalam mendiskusikan suatu permasalahan (23). Sejalan juga dengan penelitian yang dikemukakan oleh (Buhr, G.T, Heflin, M.T, 2014), bahwa metode Jigsaw efektif utuk merubah pengetahuan seseorang. Sehingga materi yang dijelaskan dapat lebih tersalurkan dengan baik dibandingkan dengan metode tradisional seperti metode ceramah yang 
dapat membuat audience bosan karena metode ceramah tidak membuat audience menjadi lebih aktif untuk berdiskusi.

Metode pembelajaran Make a Match merupakan metode pembelajaran dengan inovasi baru yang mampu mengoptimalkan hasil belajar, karena metode pembelajaran jenis ini merupakan model pembelajaran kooperatif yang menyebabkan kegiatan belajar lebih sederhana, bermakna, dan menyenangkan (25).

Hasil analisis menunjukkan bahwa adanya perbedaan pengetahuan antara kelompok Jigsaw, Make a Match dan kelompok kontrol dalam mencegah Fluor albus. Hal tersebut menunjukkan bahwa telah terjadi peningkatan mean yang lebih signifikan pada responden setelah diberikan perlakuan berupa pemberian materi mengenai pencegahan Fluor albus menggunakan metode Jigsaw dibandingkan Make a Match.

Inovasi dalam pemberian metode atau tehnik pendidikan kesehatan merupakan faktor penting dalam menunjang keberhasilan saat proses penerimaan informasi yang diberikan pada responden. Pada metode Jigsaw, responden dapat bebas berdiskusi dan menyampaikan pendapat serta pengalamannya pada anggota lain sesuai dengan materi yang telah ditentukan tanpa ada rasa malu karena para peserta berdiskusi dengan sebayanya yang berada pada kelompok-kelompok kecil beranggotakan 6 orang. Sedangkan metode pembelajaran Make a Match merupakan metode pembelajaran dengan inovasi baru yang belum pernah diberikan pada saat proses belajar mengajar maupun pendidikan kesehatan di pondok pesantren khususnya pondok pesantren Tebuireng. Sehingga responden lebih antusias dalam menerima materi yang diberikan. Adanya unsur permainan pada metode pembelajaran ini membuat suasana beajar lebih menyenangkan sehingga antusiasme responden dalam mengikuti proses pembelajaran tentang pencegahan fluor albus meningkat dan pengetahuan responden juga meningkat.

Kelompok kontrol yang tidak diberikan perlakuan, terjadi peningkatan pengetahuan namun tidak signifikan pada pre test dan post test. Hal tersebut dapat terjadi karena pengaruh dari beberapa faktor seperti faktor informasi yang didapatkan oleh responden yaitu guru.

Guru diharapkan menjadi fasilitator kesehatan bagi siswa. Keterbatasan fasilitator di sekolah dalam bidang kesehatan dapat menyebabkan masalah kesehatan belum dapat diatasi dengan baik (Fitriyah, et.al, 2013). Di pondok pesantren, guru menguasai pembelajaran bidang akademik dan agama. Namun, kurang menguasai ilmu di bidang kesehatan. Sehingga pengetahuan responden mengenai fluor albus khususnya pada kelompok kontrol tidak menunjukkan peningkatan yang signifikan karena sumber informasi yang didapatkan belum cukup untuk meningkatkan pengetahuan santriwati. Di Pondok pesantren juga belum ada fasilitas kesehatan seperti Pos Kesehatan Pesantren, sehingga para santriwati kurang maksimal dalam melakukan pemeriksaan kesehatan ke fasilitas kesehatan.

\subsection{Pengaruh Pendidikan Kesehatan Metode Jigsaw dan Make a Match terhadap Sikap Pencegahan Fluor albus pada Remaja}

Pendidikan kesehatan dengan metode Jigsaw dapat meningkatkan sikap remaja pondok pesantren dalam upaya pencegahan fluor albus pada remaja di pondok pesantren. Sesuai dengan teori Precede-Proceed, pemberian pendidikan kesehatan yang tepat dapat memanipulasi faktor predisposisi yang salah satunya adalah sikap individu. Dengan diberikannya pendidikan kesehatan yang tepat, peningkatan pengetahuan individu dapat berlanjut pada peningkatan sikap ke arah yang positif.

Metode pendidikan kesehatan yang digunakan dalam penelitian ini adalah metode Jigsaw yang merupakan metode pembelajaran berbasis kelompok (peer group discussion). Anggota kelompok didorong untuk melakukan diskusi dengan anggota yang lain mengenai materi yang telah ditentukan. Metode ini cocok diberikan pada remaja karena sesuai dengan tugas perkembangan remaja yang dikemukakan oleh (27) yaitu mengembangkan komunikasi interpersonal dengan teman sebayanya, dan memiliki kepercayaan terhadap kemampuan yang dimilikinya. Para responden diberikan kebebasan untuk berdiskusi dengan teman sekelompoknya mengenai pengalaman, ide, maupun keyakinan-keyakinan terkait fluor albus. Proses diskusi ini dapat meningkatkan kepercayaan diri reponden, karena tidak ada rasa malu maupun canggung dalam proses diskusi karena dilakukan dengan teman sebayanya.

Sejalan dengan hasil penelitian sebelumnya oleh (28), sebagian besar siswa mengungkapkan bahwa metode Jigsaw sangat membantu dalam memahami konsep materi dengan jelas, meningkatkan kemandirian, akuntabilitas, serta kepercayaan diri. Jigsaw merupakan metode pembelajaran yang menyenangkan, dapat menjadi stimulasi yang efektif sehingga kegiatan pembelajaran konvensional diupayakan diganti dengan kegiatan pembelajaran kolaboratif seperti metode Jigsaw. Berdasarkan penelitian dari (29), siswa yang diajar dengan pembelajaran Jigsaw akan memiliki sikap yang lebih positif. Siswa lebih tertarik jika proses pembelajaran dilakukan dengan cara bekerjasama dengan orang lain dan berbagi informasi dengan orang lain. Hasil penelitian (30), metode Make a Match dapat meningkatkan kegiatan belajar responden, baik kognitif maupun fisik, dan dapat meningkatkan hasil belajar. Metode ini memberikan pengalaman yang baru bagi responden sehingga menimbulkan antusiasme yang tinggi dalam mengikuti seluruh proses pembelajaran.

Hasil analisis menunjukkan bahwa adanya perbedaan sikap antara kelompok Jigsaw, Make a Match dan kelompok kontrol dalam mencegah fluor albus. Hal tersebut menunjukkan bahwa telah terjadi peningkatan mean yang lebih signifikan pada responden setelah diberikan perlakuan berupa 
pemberian materi mengenai pencegahan fluor albus menggunakan metode Jigsaw dibandingkan Make a Match. Pada kelompok kontrol yang tidak diberikan perlakuan, terjadi peningkatan sikap pada pre test dan post test namun tidak signifikan.

Pada responden kelompok perlakuan, sebagian besar responden sebelum diberikan perlakuan bersikap negatif, dan setelah diberikan perlakuan berupa pendidikan kesehatan dengan menggunakan metode Make a Match menjadi positif. Hal yang berbeda terjadi pada kelompok kontrol yang tidak menunjukkan perbedaan hasil pada pretest dan posttest sikap. Terkadang, peningkatan pada pengetahuan tidak selalu diikuti oleh peningkatan pada sikap.

Pada kelompok Jigsaw, sikap responden sebelum diberikan perlakuan masih negatif. Setelah mendapatkan pendidikan kesehatan tentang pencegahan fluor albus dengan metode Jigsaw, para responden lebih memahami mengenai cara pencegahan fluor albus, sehingga responden dapat menyikapi pernyataan-pernyataan pada kuesioner dengan lebih positif yang dapat berdampak pada perubahan sikap responden pada kelompok yang diberikan pendidikan kesehatan dengan menggunakan metode Jigsaw. Pada metode Make a Match, para responden diharuskan berpikir cepat dan kritis secara mandiri mengenai konsep yang diberikan untuk mencari jawaban yang benar karena metode ini mengharuskan masing-masing responden untuk mencari pasangan kartunya yang dibatasi oleh waktu. Selain itu, ketepatan dalam mencocokkan kartu dan pemahaman materi sesuai kartu yang telah dicocokkan juga menjadi poin penting dalam proses diskusi pada metode pembelajaran Make a Match. Sehingga responden tidak hanya bermain tetapi juga belajar berikir kritis.

4.3 Pengaruh Pendidikan Kesehatan Metode Jigsaw dan Make a Match terhadap Tindakan Pencegahan Fluor albus pada Remaja

Pendidikan kesehatan metode Jigsaw memiliki pengaruh terhadap tindakan pencegahan fluor albus pada remaja pondok pesantren. Pendidikan kesehatan dengan menggunakan metode Jigsaw merupakan stimulus yang efektif dalam merubah tindakan responden.

Berdasarkan penelitian sebelumnya oleh (17), metode pembelajaran dengan Jigsaw merupakan salah satu model cooperative learning yang menekankan pada kerjasama antar anggota kelompok yang dapat meningkatkan pengetahuan, sikap, dan keterampilan tiap anggota kelompok secara independen dan kolaboratif. Hal ini disebabkan karena adanya proses diskusi yang dilakukan pada kelompok-kelompok kecil atau peer group discussion.

Metode pembelajaran Make a Match merupakan model pembelajaran cooperative learning yang bertujuan agar para siswa dapat berperan aktif dalam proses pembelajaran yang menyenangkan dan berdiskusi dengan individu lain mengenai suatu permasalahan (18). Make a Match juga merupakan suatu proses pembelajaran yang dievaluasi dengan hasil belajar. Hasil belajar dari metode Make a Match ini dapat berupa peningkatan pada pengetahuan, sikap, keterampilan, serta nilai-nilai (dalam hal ini mengenai pencegahan perilaku pencegahan fluor albus) (31). Dengan adanya proses diskusi tersebut, terjadi proses komunikasi persuasif yang bertujuan untuk mengubah pengetahuan, sikap, dan perilaku seseorang (32).

Hasil analisis menunjukkan bahwa adanya perbedaan tindakan antara kelompok Jigsaw, Make a Match dan kelompok kontrol dalam mencegah Fluor albus. Hal tersebut menunjukkan bahwa telah terjadi peningkatan mean yang lebih signifikan pada responden setelah diberikan perlakuan berupa pemberian materi mengenai pencegahan Fluor albus menggunakan metode Jigsaw dibandingkan Make a Match. Pada kelompok kontrol yang tidak diberikan perlakuan, terjadi peningkatan sikap pada pre test dan post test namun tidak signifikan.

Peningkatan yang kurang signifikan pada kelompok kontrol juga dapat dipengaruhi oleh faktor lain yaitu informasi. Meskipun responden menerima informasi, namun proses transfer informasi tiap individu berbeda. Remaja juga merupakan usia transisi sehingga cenderung kurang mempedulikan lingkungan dan kesehatan dirinya (7). Sehingga informasi yang diterima tidak tersalurkan dan tidak terproses dengan baik oleh responden yang mengakibatkan masih banyaknya responden yang mengalami fluor albus. Selain itu, semakin lama seseorang tinggal di dalam suatu komunitas yang didalamnya terdapat prevalensi suatu penyakit, maka semakin tinggi resiko orang tersebut terjangkit penyakit tersebut yang dalam hal ini adalah fluor albus yang masih banyak dialami oleh santriwati di pondok pesantren.

Sebelum diberikan perlakuan, responden pada kelompok perlakuan memiliki tindakan pencegahan Fluor albus negatif. Namun, pada hasil observasi yang dilakukan peneliti, sebagian besar responden memiliki tindakan yang cukup. Terjadi peningkatan tindakan pencegahan fluor albus pada responden setelah dilakukan pendidikan kesehatan metode Jigsaw yang dibuktikan juga dengan adanya peningkatan tindakan pada lembar observasi yang dilakukan oleh peneliti kepada responden. Adanya perbedan hasil tindakan pada kuesioner yang diisi oleh responden dan hasil observasi yang dilakukan oleh penelitian pada pretest dapat disebabkan oleh faktor eksternal diantaranya responden sering tidak teliti dalam menjawab pertanyaan (33). Sehingga dapat menyebabkan ketidaksesuaian jawaban responden pada kuesioner dan hasil observasi yang dilakukan oleh peneliti. Hasil jawaban pada kuesioner dapat lebih rendah atau lebih tinggi dari hasil observasi yang dilakukan oleh peneliti.

Pelaksanaan intervensi berupa pendidikan kesehatan dengan menggunakan metode Jigsaw yang secara berkala yaitu sebanyak dua kali dalam seminggu serta adanya proses diskusi mandiri 
membuat responden lebih mudah dalam menyaring informasi yang didapatkan. Proses diskusi mandiri yang dilakukan dua kali (pada kelompok ahli dan kelompok awal) dalam setiap pertemuan dapat berupa informasi yang pernah diperoleh, pengalaman, pendapat, maupun tindakan yang dapat dipraktikkan oleh responden dengan menggunakan alat peraga yang telah disiapkan sesuai dengan materi yang ditentukan peneliti. Responden dapat belajar mendemonstrasikan tindakan pencegahan fluor albus secara mandiri dengan didampingi oleh fasilitator yang terdapat pada masing-masing kelompok, sehingga proses diskusi lebih fokus dan terarah.

Pada kelompok Make a Match, tindakan responden sebelum diberikan perlakuan menunjukkan hasil seimbang. Setengah dari responden memiliki tindakan negatif mengenai tindakan pencegahan fluor albus. Namun pada hasil observasi yang dilakukan oleh peneliti, tindakan responden dalam pencegahan fluor albus sebagian besar masih dalam kategori kurang. Adanya perbedaan hasil jawaban pada kuesioner yang diisi oleh responden dan hasil observasi yang dilakukan oleh peneliti dapat dipengaruhi oleh faktor lain diantaranya ketidakjujuran responden dalam menjawab pertanyaan,atau ketidakseriusan responden dalam menjawab pertanyaan. Sehingga jawaban responden pada kuesioner berbeda dengan hasil observasi yang dilakukan oleh peneliti.

Pendidikan kesehatan dengan metode Make a Match yang dilakukan secara berkala yaitu dua kali dalam seminggu serta adanya proses diskusi dan tipe pembelajaran yang menyenangkan karena terdapat unsur permainan menyebabkan responden tidak merasa bosan dan dapat meningkatkan pemahaman responden terhadap materi yang dipelajari. Adanya sesi presentasi pada metode ini tidak hanya menambah rasa tanggungjawab dan pemahaman, tetapi juga dapat meningkatkan kepercayaan diri responden untuk tampil di depan kelas dan menjelaskan materi sesuai kartu yang diperoleh pada teman-temannya.

Setelah mendapatkan pendidikan kesehatan tentang pencegahan Fluor albus dengan metode Make a Match, para responden lebih memahami mengenai cara pencegahan fluor albus, sehingga responden dapat menyikapi pernyataan-pernyataan pada kuesioner dengan lebih positif dan hasil observasi yang membaik sehingga berdampak pada perubahan tindakan responden pada kelompok Make a Match yang signifikan.

\subsection{Perbandingan Pendidikan Kesehatan dengan Metode Jigsaw dan Make a Match dalam Meningkatkan Perilaku Pencegahan Fluor Albus pada Remaja Pondok Pesantren}

Pada perbandingan pendidikan kesehatan menggunakan metode Jigsaw dan Make a Match, dapat dibuktikan bahwa metode Jigsaw memiliki pengaruh yang lebih besar dibandingkan dengan metode Make a Match dalam meningkatkan perilaku pencegahan fluor albus pada remaja di pondok pesantren. Pendidikan kesehatan metode Jigsaw dan Make a Match merupakan metode cooperative learning yang efektif dalam merubah tindakan responden dalam upaya pencegahan fluor albus. Pelaksanaan intervensi berupa pendidikan kesehatan dengan metode Jigsaw dan Make a Match yang masing-masing dilakukan secara berkala yaitu dua kali dalam seminggu serta adanya proses diskusi dapat meningkatkan perilaku remaja pondok pesantren dalam mencegah fluor albus.

Menurut teori "social cognitive theory", perilaku seseorang (dalam konteks ini perilaku pencegahan fluor albus) dipengaruhi oleh aspek kognitif. Kontribusi dari faktor kognitif yang dibentuk dari pengetahuan mengenai suatu hal dapat berkaitan dengan perilaku yang akan muncul pada diri individu (34). Perilaku seseorang dapat berpengaruh terhadap kejadian maupun status kesehatan (dalam hal ini fluor albus pada remaja pondok pesantren). Sehingga dibutuhkan upaya preventif melalui pendidikan kesehatan. Keberhasilan pendidikan kesehatan dipengaruhi oleh jumlah audiens. Semakin sedikit jumlah audience maka akan semakin efektif dalam melakukan mencapai tujuan pembelajaran (35).

Pada hasil analisis Wilcoxon Signed Test pada kelompok Jigsaw dan Make a Match pada seluruh kategori (pengetahuan, sikap, dan tindakan) menunjukkan adanya perbedaan pengetahuan, sikap, dan tindakan pada pre test dan post test. Pada hasil analisis Kruskal Wallis menunjukkan bahwa adanya perbedaan pengetahuan, sikap, dan tindakan antara kelompok Jigsaw dan kelompok Make a Match. Sehingga kedua metode memiliki pengaruh yang signifikan dalam meningkatkan pengetahuan, sikap, dan tindakan responden dalam meningkatkan upaya perilaku pencegahan fluor albus.

Dari hasil mean pada seluruh kategori (pengetahuan, sikap, dan tindakan) dapat disimpulkan bahwa pendidikan kesehatan dengan metode Jigsaw memiliki mean atau rata-rata kelompok yang lebih tinggi dibandingkan dengan metode Make a Match dan kelompok kontrol. Sehingga pendidikan kesehatan metode Jigsaw lebih efektif dalam meningkatkan perilaku pencegahan fluor albus pada remaja pondok pesantren.

Namun pada proses perubahan perilaku responden dalam mencegah flour albus, peningkatan pengetahuan tidak selalu diikuti dengan peningkatan pada sikap. Pembentukan sikap didukung oleh 3 komponen utama, yaitu: keyakinan, emosi, dan kecenderungan untuk bertindak. Penentuan sikap didukung oleh pengetahuan, pikiran, keyakinan, dan emosi (36). Sehingga, peningkatan pada sikap dalam upaya pencegahan fluor albus tidak selalu disebabkan karena peningkatan pada pengetahuan responden mengenai pencegahan fluor albus. Begitu pula peningkatan pada sikap tidak selalu diikuti dengan peningkatan pada tindakan. Sikap seseorang tidak selalu terwujud dalam suatu tindakan (overt behavior). Diperlukan faktor pendukung lain untuk mewujudkan sikap berkembang menjadi suatu 
tindakan seperti faktor dukungan dari orang lain (36).

Pendidikan kesehatan metode Jigsaw dan Make a Match masing-masing memiliki kelebihan dan kelemahan. Ditinjau dari kelebihan dan kelemahan masing-masing metode, menurut (37) pada metode Jigsaw responden dapat lebih mengembangkan ide, gagasannya dan membandingkan dengan ide, dan gagasan dari orang lain. Sehingga para individu dapat saling bertukar informasi dengan teman sebayanya tanpa ada rasa malu karena pada metode ini tidak ada sesi presentasi di depan kelas yang biasanya mengakibatkan seseorang kurang percaya diri dan mampu mengurangi kemampuannya mengungkapkan pendapatnya secara jelas dan terbuka. Selain itu, individu bebas berdiskusi dengan berbagai cara sesuai kreatifitas mereka. Mereka diberi kebebasan berdiskusi dengan menggunakan alat peraga untuk mempraktikkan suatu tindakan sesuai dengan materi yang telah ditentukan.

Pada model pembelajaran dengan menggunakan metode Make a Match menurut (38), metode ini mampu meningkatkan aktivitas belajar siswa dengan suasana belajar yang menyenangkan karena terdapat unsur permainan sehingga responden tidak merasa bosan dalam melakukan proses pembelajaran. Namun saat penerapannya, metode ini kurang efektif karena banyak responden yang gaduh dan bingung saat mencari pasangan kartunya, sehingga menciptakan suasana kelas yang kurang kondusif.

\section{KESIMPULAN}

Pendidikan kesehatan menggunakan metode Jigsaw lebih efektif dalam meningkatkan perilaku pencegahan fluor albus pada remaja pondok pesantren karena proses adanya proses diskusi (peer group discussion) dalam kelompok kecil beranggotakan 6 orang yang dilakukan dua kali pada setiap pertemuan dan adanya satu fasilitator pada setiap kelompok untuk memantau dan mengarahkan proses diskusi.

Dukungan dari perawat perlu diperhatikan dalam menerapkan pendidikan kesehatan dengan metode Jigsaw dan Make a Match dalam berbagai kegiatan pembelajaran maupun pendidikan kesehatan. Selain itu, dukungan dari instansi dan lembaga pendidikan perlu diperhatikan dalam menggunakan metode Jigsaw dan Make a Match sebagai referensi metode belajar bagi lembaga pendidikan dalam meningkatkan perilaku pencegahan fluor albus pada remaja di pondok pesantren maupun lembaga pendidikan lainnya. Peneliti selanjutnya diharapkan dapat menggunakan penelitian ini untuk mengembangkan intervensi keperawatan yaitu promosi kesehatan yang dapat meningkatkan perilaku pencegahan penyakit yang lain.

\section{UCAPAN TERIMA KASIH}

Kami mengucapkan terima kasih kepada Ketua Majelis Pimpinan Pondok Pesantren Darul Ulum , Ketua Pengasuh Pondok Pesantren Darussalam,
Ketua Pengurus Pondok Pesantren Tebuireng yang telah mengizinkan dan menerima saya untuk mengambil data sebagai bahan penelitian, serta seluruh santriwati yang telah bersedia menjadi responden.

\section{DAFTAR PUSTAKA}

1. Rakhmilla. L, Fah. L, Yulia. S, Widjajakusuma. A RN. Knowledge, Attitude, and Practice about Vaginal Discharge on School-Age Girls in Jatinangor Senior High School. OALib. 2016;03(11):1-9.

2. Yang ' H-T, Yao ' L-J, Wu ' L-Y, Huan<j2 Z-W, Wen ' H-T, Chen ' D-T, et al. Status of reproductive health knowledge for junior high school students in Guangzhou city. J ofReproduction Contracept Mar. 2016;27(1):41-9.

3. Matthews JD. Health literacy among female university students in the United Arab Emirates. Int J Heal Promot Educ. 2018;00(00):1-11.

4. Brunette C. Feeling healthy: how teacher personal health beliefs influence roles for promoting student health. Int J Heal Promot Educ. 2017;5240(November):0.

5. Mancuso AC, Ryan GL. Normal Vulvovaginal Health in Adolescents. J Pediatr Adolesc Gynecol. 2015;28(3):132-5.

6. Syed TS, Braverman PK. Vaginitis in adolescents. Adolesc Med Clin. 2004;15(2):235-51.

7. Nazira A, Devy SR. Pengaruh Persona Reference, Thought and Feeling Terhadap Kesehatan Reproduksi Santri Putri Pondok Pesantren X. J Promosi Keseahatan. 2015;3(2):229-40.

8. Sulistiyowati. Perbedaan Efektifitas Penggunaan Daun Sirih dan Bawang Putih terhadap Fluor Albus. 2016;08(03).

9. Setyowati. S. Hubungan Sanitasi Pondok Pesantren dan Personal Hygiene Dengan Kejadian Keputihan (Fluor Albus) pada Remaja Putridi Pondok Pesantren Al-Lathifiyah Bahrul Ulum Tambak Beras Jombang. J Kesehat Masy. 2013;

10. Poureslami M, Osati-Ashtiani F. Assessing knowledge, attitudes, and behavior of adolescent girls in suburban districts of Tehran about dysmenorrhea and menstrual hygiene. J Int Womens Stud. 2002;3(2):1-11.

11. Sa'adatun. U, Widyasih. H. Personal Hygiene Habits dan Kejadian Flour Albus Patologis pada Santriwati PP AL-Munawwir , Yogyakarta Santriwati of PP Al-Munawwir , Yogyakarta. J Kebidanan. 2018;36-43.

12. Chirenje ZM, Dhibi N, Handsfield HH, Gonese E, Tippett Barr B, Gwanzura L, et al. The Etiology of Vaginal Discharge Syndrome in Zimbabwe: Results from the Zimbabwe STI Etiology Study. 
Sex Transm Dis Assoc. 2018;45(6):422-8.

13. Cemek F, Odabaş D, Şenel Ü, Kocaman AT. Personal Hygiene and Vulvovaginitis in Prepubertal Children. J Pediatr Adolesc Gynecol. 2016;29(3):223-7.

14. McGreal S, Wood P. Recurrent Vaginal Discharge in Children. J Pediatr Adolesc Gynecol. 2013;26(4):205-8.

15. Sharma A. A Pre-experimental Study to Assess the Effectiveness of Structured Teaching Program on Leucorrhoea among Nursing Students in Hgpi Kala- Amb. 2018;1-7.

16. Affarudin I. Penerapan Metode Pembelajaran Make a Match dengan Macromedia Flash untuk Meningkatkan Hasil Belajar Biologi dan Keaktifan Siswa Materi Pokok Gerak pada Tumbuhan Kelas VIII MTs Negeri Tanon Kabupaten Sragen, Surakarta. Univ Muhammadiyah Surakarta. 2012;

17. Leyva-Moral JM, Riu Camps M. Teaching research methods in nursing using Aronson's Jigsaw Technique. A cross-sectional survey of student satisfaction. Nurse Educ Today. 2016;40:78-83.

18. Hidayah. N, Suharno IM. The Implementation of Cooperative Learning by Using Jigsaw and Make a Match Method to Improve the Activity and Learning Outcomes of Social Science. 2016;2(1):284-9.

19. Petty.RE C. Communication and Persuasion. New York: Springer-Verlag; 1986.

20. Khedr N, Awad H, Elmashad M, Al-Wehedy A. Vaginal Secretions among Students in the Egyptian Universities: Prevalence, Knowledge and Practices. World J Nurs Sci. 2015;1(3):6875.

21. Cepeda, N., Pashler, H., Vul, E., Wixted., J., \& Rohrer D. Distributed Practice in Verbal Recall Tasks: A Review and Quantitative Synthesis. Psycological. 2006;132,354-38.

22. Gintings A. Esensi Praktis Belajar \& Pembelajaran: Disiapkan untuk Pendidikan Profesi dan Sertifikasi Guru-Dosen. Bandung: Humaniora; 2008.

23. Bhandari B, Mehta B, Mavai M. Medical Education / Original Article Jigsaw Method : An Innovative Way of Cooperative Learning in Physiology. 2017;61(3):315-21.

24. Buhr, G.T, Heflin, M.T, White,H.K, Pinheiro S. Using the Jigsaw Cooperative Learning Method to Teach Medical Students about Long-Term and Postacute Care (Abstract). J Am Med Dir Assoc.
$2014 ; 15$.

25. Dewi L. Pengaruh Model Pembelajaran Kooperatif Tipe Make a Match berbantuan Media Grafis terhadap Hasil Belajar IPS Siswa Kelas V SDN 18 Pemecutan. J Mimb PGSD Univ Pendidik Ganesha Jur PGSD. 2013;

26. Fitriyah, N, Indriani, D., Sulistyorini Y. Riwayat Kesehatan Reproduksi Remaja Santri. J Biometrika dan Kependud. 2013;2:189-92.

27. Yusuf S. Psikologi Perkembangan Anak dan Remaja. Bandung: PT Remaja Rosdakarya; 2000.

28. Ali, Nadia. Ali M. Playing jigsaw : A cooperative learning experience. J Nurs Educ. 2001;40(9):16-9.

29. Tran VD, Lewis RR. Effects of cooperative learning on students at an giang university in Vietnam. Int Educ Stud. 2012;5(1):86-99.

30. Wiguna, A. Sumantri, R. Pengaruh Model Pembelajaran Kooperatif Tipe Make a Match Terhadap Hasil Belajar Matematika Siswa Kelas IV Di Gugus III Kecamtan Rendang. J Mimb PGSD Univ Pendidik Ganesha Jur PGSD. 2014;2(1):3641.

31. Lazim N, Aldriyanti N, Alpusari M, Hermita N, Mahbubah K. Utilizing Cooperative Learning Model Types Make a Match toPromote Primary Students ' Achivement in Science. 2018;1(1):1121.

32. Hayati, E. Purba AA. Pengaruh Komunikasi Persuasif Bidan Terhadap Pengetahuandan Sikap Ibu tentang Pemberian MP-ASI di Desa Pasar Maga Kecamatan Lembah Sorik Merapu Kabupaten Mandailing Natal. 2016;

33. Arikunto S. Prosedur Penelitian Suatu Pendekatan Praktik. Jakarta: Rineka Cipta; 2010.

34. Ibrahim K, Mardiah W, Priambodo AP. Pengetahuan, sikap, dan praktik kewaspadaan universal perawat terhadap penularan HIV/AIDS. J Ners. 2014;9:11-8.

35. Mulyanti S, Astuti AB. Effects of Health Education on Leptospirosis Prevention through Dasawisma. J Ners. 2018;13(1).

36. Notoatmodjo S. Promosi Kesehatan dan Ilmu Perilaku. Jakarta: Rineka Cipta; 2010.

37. Aronson E. Building Empathy, Compassion, and Achievement in the Jigsaw Classroom. Improv Acad Achiev Impact Psychol Factors Educ. 2002;209-25.

38. Huda M. Model-model Pengajaran dan Pembelajaran. Yogyakarta: Pustaka Belajar; 2013. 